\title{
OUTCOMES OF SURGICAL TREATMENT OF LUMBAR DISK HERNIATION USING AN ANNULAR CLOSURE DEVICE
}

\author{
DESFECHOS DO TRATAMENTO CIRÚRGICO DA HÉRNIA DE DISCO LOMBAR \\ COM APARELHO DE FECHAMENTO ANULAR \\ RESULTADOS DEL TRATAMIENTO QUIRÚRGICO DE LA HERNIA DE DISCO LUMBAR \\ UTILIZANDO UN DISPOSITIVO DE CIERRE ANULAR
}

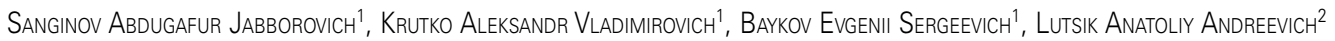

1. Novosibirsk Research Institute of Traumatology and Orthopaedics (NRITO) n.a. Ya.L. Tsivyan, Novosibirsk, Russia.

2. Novokuznetsk State Institute of Advanced Medical Education, Novokuznetsk, Russia.

\begin{abstract}
Objective: The aim of the study was to investigate the clinical and radiological results of using the annular closure device in patients with lumbar disc herniation (LDH). Methods: The study involved 120 patients with LDH operated on by limited discectomy and annular closure using the Barricaid device. A literature review was conducted to evaluate the effectiveness of the annuloplasty. Results: All patients showed postoperative regression of the radicular pain syndrome and were mobilized on the day of surgery. The correlation between the removed nucleus pulposus and changes in $\mathrm{DHI}$ was studied by linear regression. The results revealed that disc height loss is directly correlated with the volume of removed nucleus pulposus $(p<0.05)$. Modic changes were present in $22(22 \%)$ patients. Endplate changes (resorption and erosion) were present in 25 patients (20.7\%). We found that these changes in MR and CT images have no effect on the clinical presentation of the disease. No intraoperative complications, such as severe hemorrhage requiring blood transfusion, or injury to the dura mater or nerve roots, were observed in our case series. Postoperative complications occurred in $3(2.5 \%)$ patients. The reoperation rate was $4.2 \%$. Conclusions: The use of the Barricaid annular closure device in 120 patients with lumbar disc herniation and high risk of recurrent herniation showed good clinical and radiographic outcomes. The reoperation rate in our study was $2.5 \%$; disc reherniation at the operated level was observed in $1.7 \%$ of patients. This is a good outcome compared to the data reported for patients having a high risk of disc reherniation. Level of Evidence IV; Case series.
\end{abstract}

Keywords: Intervertebral disc displacement; Annulus fibrosus; Diskectomy; Bone plate.

\section{RESUMO}

Objetivo: O objetivo do estudo foi estudar os resultados clínicos e radiológicos do uso do dispositivo de fechamento anular em pacientes com hérnia discal lombar (HDL). Métodos: O estudo envolveu 120 pacientes com LDH operados por discectomia limitada e fechamento anular usando o dispositivo Barricaid. Uma revisão da literatura foi realizada para avaliar a eficácia da anuloplastia. Resultados: Todos os pacientes apresentaram regressão pós-operatória da síndrome da dor radicular e foram mobilizados no dia da cirurgia. A correlação entre o núcleo pulposo removido e as alterações no DHI foi estudada por regressão linear. Revelou-se que a perda de altura discal está diretamente correlacionada com o volume do núcleo pulposo removido $(p<0,05)$. Alterações modicadas reveladas em 22 (22\%) pacientes. As alterações no endplate foram reveladas em 25 pacientes (20,7\%). Descobrimos que essas mudanças nas imagens de RM e TC não têm efeito sobre a apresentação clínica da doença. Não foram observadas complicações intraoperatórias, como hemorragia grave que necessitou de transfusão sanguínea, lesão da dura-máter ou raízes nervosas, em nossa casuística. Complicações pós-operatórias foram reveladas em 3 (2,5\%) pacientes. A taxa de reoperação foi de 4,2\%. Conclusão: O uso do dispositivo de fechamento anular Barricaid em 120 pacientes com hérnia discal lombar e alto risco de hérnia recorrente mostrou bons resultados clínicos e radiográficos. A taxa de reoperação em nosso estudo foi de 2,5\%; reinteriato discal no nível operado foi observado em $1,7 \%$ dos pacientes. É um bom resultado comparado aos dados relatados para pacientes com alto risco de reintervenção com disco. Nível de evidência IV; Série de casos.

Descritores: Deslocamento do Disco Intenvertebral, Anel Fibroso, Discotomia, Placas Ósseas.

\section{RESUMEN}

Objetivo: El objetivo del estudio fue estudiar los resultados clínicos y radiológicos del uso del dispositivo de cierre anular en pacientes con hernia de disco lumbar (LDH). Métodos: El estudio involucró a 120 pacientes con LDH operados por discectomía limitada y cierre anular usando el dispositivo Barricaid. Se realizó una revisión de la literatura para evaluar la efectividad de la anuloplastia. Resultados: Todos los pacientes mostraron regresión postoperatoria del síndrome de dolor radicular y se movilizaron el día de la cirugía. La correlación entre el núcleo pulposo retirado y los cambios en DHI se estudiaron mediante regresión lineal. Los resultados revelaron que la pérdida de altura del disco se correlaciona directamente con el volumen del núcleo pulposo retirado $(p<0,05)$. Cambios módicos revelados en $22(22 \%)$ pacientes. Los cambios de placa terminal (resorción y erosión) se revelaron en 25 pacientes (20,7\%). Descubrimos que estos cambios en las imágenes de RM y TC no tienen ningún efecto sobre la presentación clínica de la enfermedad. En nuestra serie de casos no se 
observaron complicaciones intraoperatorias, como hemorragia severa que requiriera transfusión de sangre, lesión de la duramadre o raíces nerviosas. Las complicaciones postoperatorias se revelaron en 3 (2,5\%) pacientes. La tasa de reoperación fue del 4,2\%. Conclusiones: El uso del dispositivo de cierre anular Barricaid en 120 pacientes con hernia de disco lumbar y alto riesgo de hernia recurrente mostró buenos resultados clínicos y radiográficos. La tasa de reoperación en nuestro estudio fue del $2.5 \%$; la hernia recurrente del disco en el nivel operado se observó en el 1,7\% de pacientes. Es un buen resultado en comparación con los datos informados para pacientes que tienen un alto riesgo de hernia recurrente del disco. Nivel de evidencia IV; Serie de casos.

Descriptores: Desplazamiento del Disco Intervertebral; Anillo Fibroso; Discectomía; Placas Óseas.

\section{INTRODUCTION}

Microdiscectomy is the most common elective surgery performed in patients with degenerative lumbar spine disorders. Although the good success rate of discectomy is widely recognized, $10-30 \%$ of patients still experience low back pain and/or leg pain after the surgery. ${ }^{1}$ Patient satisfaction one year after the surgery is approximately $75 \%$, while $20 \%$ of patients are reoperated during the first 3 years. ${ }^{2-5}$ Disc height loss and recurrent disc herniation are the key reasons for the relapsing pain syndrome and, therefore, reoperation. ${ }^{6-9}$

According to the published data, the overall risk of lumbar disc reherniation is $2-18 \% .3,6,10-14$ There is convincing evidence that the recurrence rate depends on the size of the annular defect and the volume of nucleus pulposus removed. The risk of recurrence is $\sim 1 \%$ in patients with a small or fissure-like annular defect and $18-27 \%$ in patients with larger defects. ${ }^{15}$ Therefore, for larger defects, several questions regarding the surgical tactics arise. The question of the degree of aggressiveness of the discectomy when treating patients with lumbar disc herniation remains unresolved. Each technique has its own advantages and disadvantages. Aggressive discectomy results in loss of disc height, increased load on the facet joints followed by facet joint hypertrophy, development of segmental instability, and degenerative stenosis. ${ }^{16}$ Limited discectomy leaves most of the nucleus pulposus remaining, which creates a potential source of reherniation.

The annular closure device (ACD) following limited microdiscectomy is a modern and promising procedure in spine surgery. The concept of ACD is based on a number of favorable factors: preserving the disc height, preventing recurrent herniation due to the barrier function, reducing lumbodynia due to conservative microdiscectomy, and slowing down the degenerative cascade of both the intervertebral disc and facet joints of the segment. ${ }^{9}$

The device used to close the annular defect, the Barricaid ${ }^{\circledR}$ implant, was designed by Intrinsic Therapeutics (Woburn, MA, USA) to prevent recurrent disc herniation following limited microdiscectomy. The amount of data on the effectiveness of using Barricaid in large patient cohorts accumulated thus far is insufficient. In 2009, an RCT involving over 500 patients was started; however, it is not yet complete, and the results have not been reported to the global research community. Thus, prospective studies to evaluate the effectiveness of using the ACD are relevant.

\section{METHODS}

\section{Study design and patient selection}

We have planned and conducted a single-center prospective study to assess the effectiveness of ACD. The inclusion criteria were posterolateral herniation at L3-L4, L4-L5, L5-S1 levels, and intervertebral disc height in the posterior regions assessed by lateral radiography of the lumbar spine $\geq 5 \mathrm{~mm}$. The exclusion criteria were: spondylolisthesis, segmental instability, spinal stenosis, lumbar scoliosis, earlier surgical interventions at the operated level, osteoporosis (T-score < -2.0), abnormalities and non-degenerative lesions of lumbar spine, and decompensated concurrent diseases. The final decision on implantation was made intraoperatively once the annular defect had been visualized and its size quantified. The study involved 120 patients with lumbar disc herniation operated on by limited microdiscectomy and annular closure using the Barricaid device. In one patient, surgical management involving implantation of the Barricaid device was performed at two levels (L4-L5, L5-S1). Hence, we analyzed 121 cases in which the Barricaid implant was used.

All patients were operated on at Neurosurgical Department no. 2 of the Ya.L. Tsivyan Research Center of Traumatology and Orthopedics in 2012-2017 (inclusive).

All patients underwent clinical neurologic examination and radiography. Pain intensity and the disability index were evaluated using the Visual Analogue Scale (VAS) and the Oswestry scale. Indications for surgery were disc herniation confirmed by neuroimaging (CT/ $\mathrm{MRI}$ ) and the presence of relevant clinical manifestations resistant to conservative treatment for 6 weeks.

\section{Radiographic Measures}

The combination of instrumented examination methods included X-ray of the lumbar spine in two projections with functional tests (flexion, extension), and CT and MRI of the lumbar spine. The radiographic data were used to evaluate lumbar lordosis, sagittal plane segmental motion, and the disc height index. ${ }^{17}$ This parameter was measured in the lateral radiograph as a ratio between the heights of the intervertebral disc and the body of the superjacent vertebra. MRI of the lumbar spine allowed us to visualize the substrate, in order to determine the type of herniation, its location, the Pfirrmann disc degeneration grade, ${ }^{18}$ facet joint degeneration according to Grogan's classification, ${ }^{19}$ and Modic changes in the endplates of the adjacent vertebral bodies. All patients underwent preoperative lumbar spine CT to evaluate the bone tissue, reveal erosive changes in the endplates of the adjacent vertebral bodies, and determine the presence of intervertebral disk vacuum phenomenon. Implant position and the condition of bone tissue around the implant anchor and mesh were analyzed using the CT data during the follow-up.

\section{Surgical technique}

Surgery was performed under general anesthesia. The patients were positioned on the operating table in a knee-chest position. After cleansing the skin at the surgical site with antiseptic solution, the skin was incised along spinous processes at the level of surgery to isolate spinous processes and the interarch space at the herniation site. Next, we conducted interlaminectomy, revision of the spinal canal, detection of disc herniation, and transection of the posterior longitudinal ligament. Disc herniation and free fragments of the posterior disc portions were removed. The size of the annular defect was measured using templates. The annular closure device was implanted under control of an electronic image converter, according to the size of the annular defect. Hemostasis was achieved and the wound was closed layerwise. The volume of the removed disc herniation was measured in all cases. The patients were mobilized on the day of surgery.

The study was conducted according to good clinical practice, which ensures that the design, implementation, and communication of data are reliable, that the patients' rights are protected, and that confidentiality of the subject's data is maintained. The study was approved by the local ethics committee of the Ya.L.Tsivyan Research Center of Traumatology and Orthopedics (protocol No. 083/17). All patients provided written informed consent, which included their consent for the use of their data in the analyses, and its presentation. 


\section{Data collection}

The key patient characteristics (sex, age, body mass index, and smoking status) were collected at the preoperative stage. The clinical data (neurological status, VAS pain intensity score, and the Oswestry disability index preoperative, immediately after surgery, during the follow-up, and during the postoperative period) were accumulated. The following parameters related to the surgery were collected: duration of surgery, blood loss volume, size of annular defect, volume of the removed disc herniation, and complications.

\section{Data collection: time points}

The outcomes of surgical treatment were evaluated 3, 6, 12, 24, 36, 48 , and 60 months after surgery. The VAS score of pain intensity in the spine and leg, the Oswestry disability index, and the neurological status were assessed at all follow-up points; radiography of the lumbosacral spine was also performed. MRI and MSCT of the lumbar spine were performed 6 and 12 months after surgery and once a year thereafter.

\section{Statistical methods}

We used an R Statistical Package (http://www.r-project.org) for the calculations. Descriptive statistics were reported as absolute frequencies or as median values with IQR. Depending on the type of data to be processed, we used the Mann-Whitney $U$ test, Pearson's chi-squared test, or the Exact Fisher Test and non-parametric Kruskal-Wallis analysis of variance by rank and median multiple comparisons.

All the reported $p$ values were based on two-tailed tests for significance, and $p$ values $<0.05$ were considered statistically significant. We used the software programs STATISTICA 7.0 (StatSoft, Tulsa, OK, USA) and RStudio version 0.99.484 (Free Software Foundation, Inc., Boston, USA) with R packages version 3.2.2 (The R Foundation for Statistical Computing, Vienna, Austria) for the analyses.

\section{RESULTS}

Table 1 shows the general characteristics of the patients. Patients aged 17-63 years were enrolled, with males predominating (53.3\%). Lumbar disc herniation mainly presented as radicular pain. Neurological disorders presenting as hypoesthesia and weakness in the innervation zone of a compressed spinal nerve root were observed in $33.3 \%$ of patients. Surgery was performed at three lower lumbar levels, mostly at the L5-S1 level (51.7\%).

\section{Clinical outcomes}

All patients showed postoperative regression of the radicular pain syndrome and were mobilized on the day of surgery. The VAS scores showing pain intensity in leg and back preoperatively, at discharge, and after $3,6,12,24,36,48$, and 60 months, are shown in Figure $1 \mathrm{a}, \mathrm{b}$.

The disability index was evaluated using the Oswestry questionnaire. A reliable reduction in the Oswestry disability index (improvement in the quality of life) was observed at all follow-up points. (Figure 2)

\section{Radiological results}

The herniation type (protrusion, extrusion, or sequestration) was determined from the MR scans, according to the nomenclature proposed by the North American Spine Society in $2001 .{ }^{20}$ Protrusion $(47.5 \%)$ was the most common type, while extrusion and sequestration were observed in 25.8 and $26.7 \%$ of cases, respectively.

The disc height index (DHI) was calculated using the formula: $\mathrm{DHI}=\mathrm{a} / \mathrm{A}$, where $\mathrm{a}$ and $\mathrm{A}$ is the height of the intervertebral disc and the superjacent vertebra, respectively. ${ }^{17}$ Assessment of the dynamics of changes in the disc height index showed no significant reduction in this parameter at the follow-up points $(p=0.541)$. (Figure 3$)$ Analysis of the height index of the disc within one year of surgery showed that this parameter mostly decreased in the first three months (loss $6.59 \pm 0.72 \%)$. In the second quarter and half-year after the operation, the losses were $3.56 \pm 0.56 \%$ and $4.01 \pm 0.64 \%$, respectively.

Intervertebral disc collapse after most of the nucleus pulposus had
Table 1. General characteristics of the patients.

\begin{tabular}{|c|c|c|}
\hline Evaluation parameters & Value & $\%$ \\
\hline \multicolumn{3}{|c|}{ Number of patients, 120; number of operated levels, 121} \\
\hline \multicolumn{3}{|l|}{ Sex } \\
\hline males (\%) & 64 & 53.3 \\
\hline females (\%) & 56 & 46.7 \\
\hline Age, years & 37.6 & - \\
\hline $\mathrm{BMI}$ & 26.6 & - \\
\hline \multicolumn{3}{|l|}{ Smoking status } \\
\hline Positive (\%) & 63 & 52.5 \\
\hline Negative (\%) & 57 & 47.5 \\
\hline Number of bed days & 7.8 & - \\
\hline Surgery duration, min & 57.1 & - \\
\hline Volume of blood loss, $\mathrm{ml}$ & 79.7 & - \\
\hline \multicolumn{3}{|l|}{ Symptoms of the disease } \\
\hline Pain & 80 & 66.7 \\
\hline Pain + hypoesthesia and/or leg weakness & 40 & 33.3 \\
\hline \multicolumn{3}{|l|}{ Operated level (\%) } \\
\hline L3-L4 & 6 & 4.96 \\
\hline L4-L5 & 52 & 42.98 \\
\hline L5-S1 & 63 & 52.07 \\
\hline \multicolumn{3}{|l|}{ Herniation side $(\%)$} \\
\hline right-sided & 52 & 42.98 \\
\hline left-sided & 69 & 57.02 \\
\hline \multicolumn{3}{|l|}{ Herniation type (\%) } \\
\hline protrusion & 60 & 49.59 \\
\hline extrusion & 29 & 23.97 \\
\hline sequestration & 32 & 26.45 \\
\hline Annular defect area, $\mathrm{mm}^{2}$ & 47.3 & - \\
\hline Disc volume, $\mathrm{cm}^{3}$ & 11.7 & - \\
\hline $\begin{array}{c}\text { Volume of the removed disc herniation } \\
\text { ( } \% \text { of the total disc volume) }\end{array}$ & 1.5 & 12.8 \\
\hline Follow-up period, months & 18.9 & - \\
\hline
\end{tabular}

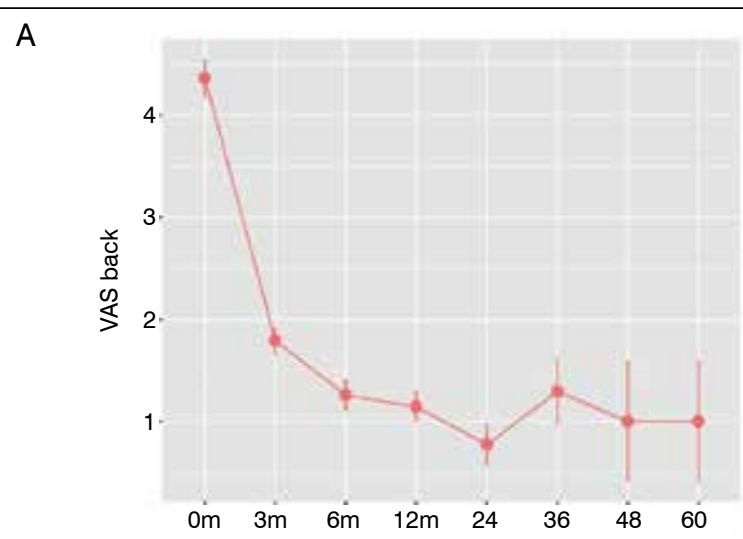

B

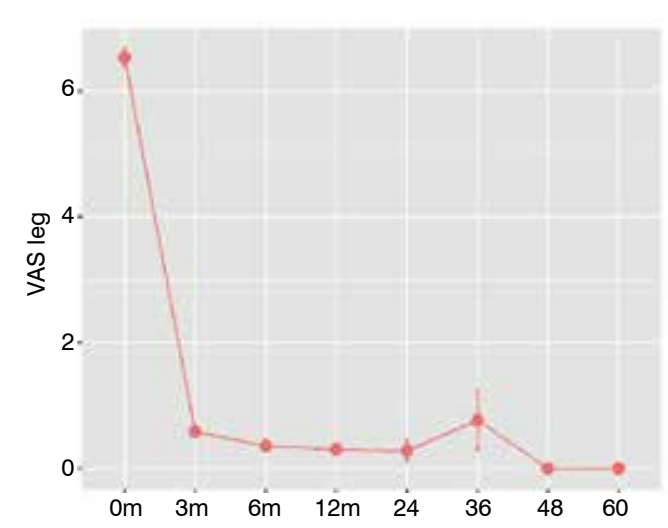

Figure 1. The dynamics of changes in VAS score: A - VAS back $(p=0.023)$; $B$ - VAS leg $(p=0.001)$. 


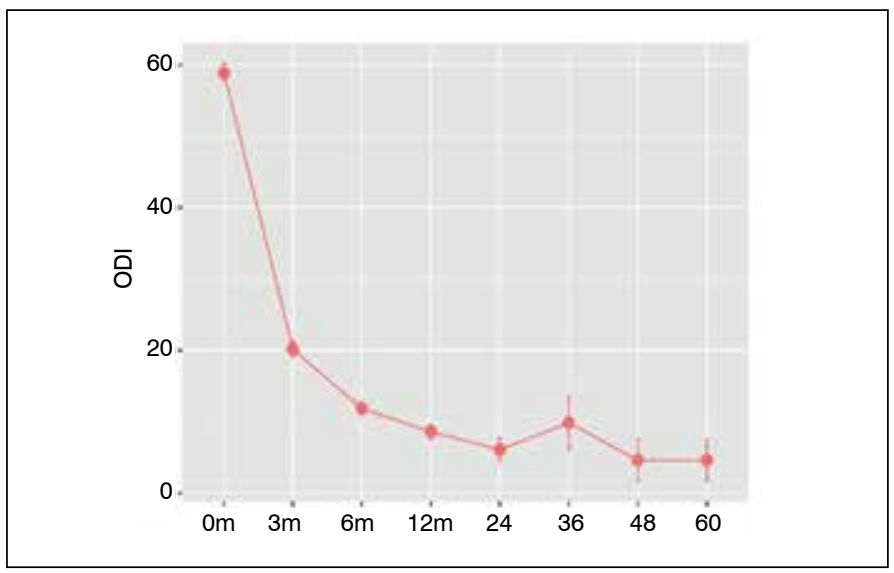

Figure 2. The dynamics of changes in the Oswestry disability index (ODI). $p=0.001$.

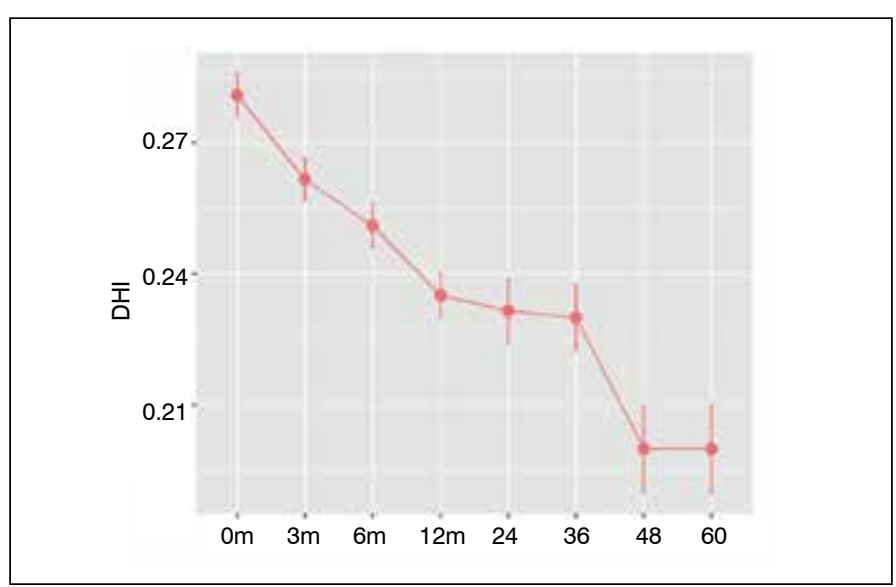

Figure 3. Disc height loss after operation (3-60 months), (DHI-disc height index).

been removed was one of the reasons for the unfavorable outcome of microdiscectomy. The correlation between the removed nucleus pulposus and changes in $\mathrm{DH}$ was studied by linear regression.

We studied the difference (\%) between the DHI 12 months after the surgery and the preoperative $\mathrm{DHI}$ and it revealed that disc height loss directly correlated with the volume of removed nucleus pulposus. In both cases, p was $<0.05$. (Figure 4)

Retrolisthesis at the operated level was revealed in 29 (24.2\%) patients. Assessment of the VAS scores for back and leg pain severity and ODI showed no intergroup difference $(p>0.05)$ in disc height loss in patients with and without retrolisthesis at postoperative follow-up points of six-12 months.

\section{Endplate changes}

Preoperative lumbar spine MRI showed Modic changes in endplates in $20(16.7 \%)$ patients. Of the 100 patients with no Modic changes prior to surgery, 22 (22\%) patients presented these changes postoperatively. Table 2 shows the type and time of emergence of Modic changes.

Preoperative CT images showed erosive changes and resorption foci of endplates of the superjacent and subjacent vertebra in 12 $(10 \%)$ and five $(4.2 \%)$ patients, respectively. The area affected by these changes increased postoperatively. Resorption foci of the superjacent vertebra (around the polyethylene terephthalate mesh) were revealed in 20 patients at different follow-up points, while resorption foci of the subjacent vertebra were detected in five patients. Resorption foci around the polyethylene terephthalate mesh emerged in patients in whom the mesh end was contacting the body of an adjacent vertebra as a result of disc height loss.

Assessment of the dynamics of changes in the disc height index in patients with bone resorption around the mesh showed a

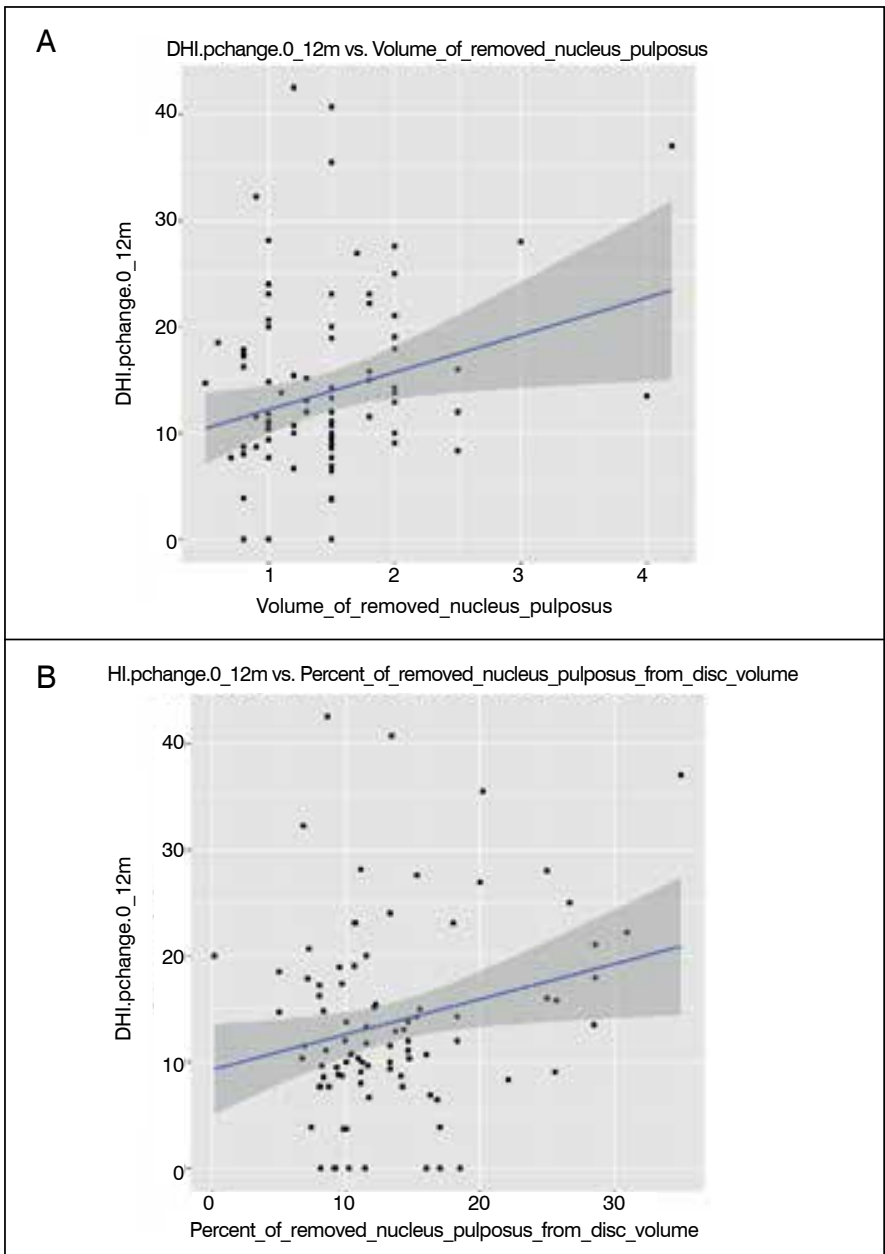

Figure 4. The difference in preoperative $\mathrm{DHI}$ and $\mathrm{DHI} 12$ months after the surgery (\%) as a function of the volume of the removed nucleus pulposus; left image: Volume of the removed nucleus pulposus (cm3); right image: Percentage of the removed nucleus pulposus with respect to total disc volume.

Table 2. Modic changes.

\begin{tabular}{c|c|c|c|c|c|c|c}
\hline Period & \multirow{2}{*}{$\begin{array}{c}\text { Preoperative } \\
\text { period }\end{array}$} & \multicolumn{6}{|c}{ Follow-up period (months) } \\
\cline { 3 - 8 } Modic & & $\mathbf{6}$ & $\mathbf{1 2}$ & $\mathbf{2 4}$ & $\mathbf{3 6}$ & $\mathbf{4 8}$ & $\mathbf{6 0}$ \\
\hline I & 13 & $4^{*}$ & 1 & 3 & - & 1 & - \\
\hline II & 6 & 5 & 3 & 2 & 2 & - & - \\
\hline III & 1 & - & 0 & 1 & - & - & - \\
\hline Total & 20 & 9 & 4 & 6 & 2 & 1 & - \\
\hline
\end{tabular}

reduction in this parameter during follow-up $(p=0.542)$ (figure 5).

As a result of the loss of disk height, the mesh with the endplate of adjacent vertebra has come into contact, leading to the appearance of a resorption area.

We found by non-parametric 2-way ANOVA that these changes in MR/CT images have no effect on clinical presentation of the disease. (Table 3)

\section{Recurrent disc herniation}

Ipsilateral and contralateral disc reherniation at the operated level was revealed in one patient each $(0.8 \%)$. Both patients underwent reoperation. (Table 4) No contralateral disc herniation was revealed in the remaining cases.

Two (1.7\%) patients developed disc reherniation without signs of compression of neural structures. Lumbar spine MRI 12 and 18 months after the surgery revealed ipsilateral reherniation at the 
operated level. However, the patients did not complain of pain in the lumbar spine and lower extremities during examination. These patients were followed up.

\section{Complications and reoperations}

There are risks of complications associated with using the Barricaid annular closure device. Its implantation requires sufficiently large interlaminar and intracanal spaces for impaction, which is ensured by sufficiently high traction of the nerve root and the dural sac and may cause injury to these structures. As with any other implant, there is a risk of implant migration, subsidence, and mechanical damage, and also of an allergic response to it.

No intraoperative complications, such as severe hemorrhage requiring blood transfusion, or injury to the dura mater or nerve roots, were observed in our case series. Postoperative complications were revealed in three $(2.5 \%)$ patients. One patient had an epidural hematoma requiring revision surgery. One patient exhibited aggravation of neurological symptoms: increased severity of hypoesthesia of the affected area, which completely subsided within three months. One patient developed post-catheterization thrombophlebitis of the subcutaneous vein of the left forearm; conservative treatment was carried out according to the angiosurgeon's recommendations.

Reoperation rate was $4.2 \%$. (Table 5)

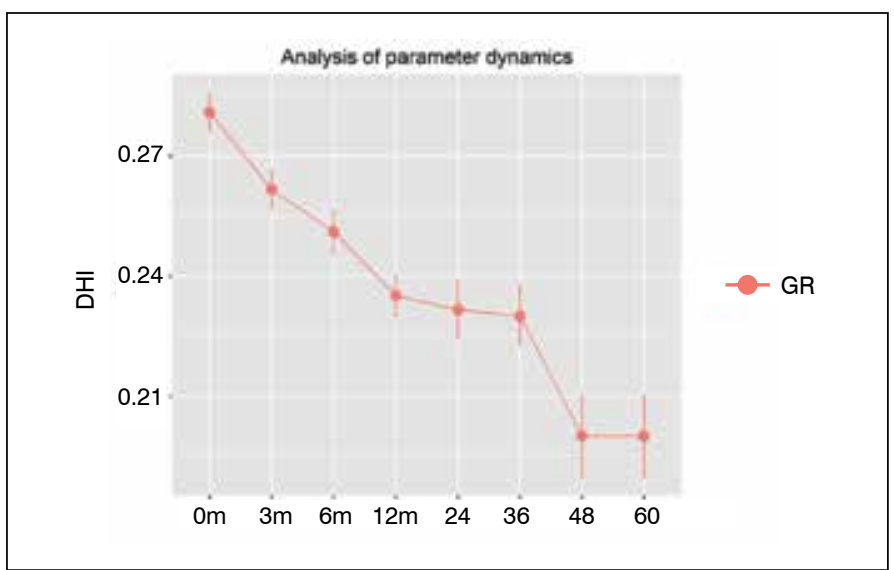

Figure 5. Dynamics of changes in the disc height index in patients with foci of resorption around the Mesh.

Table 3. Modic changes, bone resorption and VAS \& ODI scores.

\begin{tabular}{c|c|c|c}
\hline & VAS back & VAS leg & ODI \\
\hline Patients with Modic changes & $2(1.5: 2.65)$ & $\begin{array}{c}1.75 \\
(1.5: 2.31)\end{array}$ & $\begin{array}{c}22.08 \\
(17.58: 30)\end{array}$ \\
\hline Patients without Modic changes & $2.33(1.82: 3)$ & $1.8(1.5: 3)$ & $\begin{array}{c}25 \\
(21.17: 34.42)\end{array}$ \\
\hline p value & 0.095 & 0.287 & 0.119 \\
\hline Patients with bone resorption & $5(2: 6)$ & $7(6: 8)$ & $60(52: 62)$ \\
\hline Patients without bone resorption & $4(4: 6)$ & $6(5: 7.25)$ & $\begin{array}{c}57 \\
(48.67: 68.5)\end{array}$ \\
\hline$p$ value & 0.831 & 0.223 & 0.728 \\
\hline
\end{tabular}

The Barricaid annular closure device was removed and posterior interbody fusion using transpedicular fixation was performed in 4 cases. Three (2.5\%) patients in our series were reoperated because of segmental instability. These patients had preoperative segmental instability that has not been evaluated, although the radiographic data showed no instability. However, the pain syndrome can significantly limit the applicability of this method. In one patient, removal of the implant (ipsilateral disc reherniation at the operated level) was technically challenging, since the implant was tightly fused with the vertebral body. Neurological deficit in this patient worsened continuously: the leg weakness was aggravated. Control examination after 3 months showed regression of neurological deficit to reach the preoperative level. In other patients, implant removal was not associated with any difficulties.

\section{DISCUSSION}

The use of the Barricaid annular closure device aims to reduce the rate of recurrent herniation due to its barrier function, to reduce lumbodynia by maintaining the disc height because of limited discectomy, and to slow down the degenerative cascade of both the intervertebral disc and facet joints of the spinal motion segment.

We studied the results of using the annular closure device in patients with lumbar disc herniation with a high risk of recurrent herniation. The risk of reherniation was considered high if a patient had an annular defect and had undergone limited microdiscectomy (sequestrectomy). In their review, Watters et al. demonstrated that the high rate of lumbar disc reherniation depended on the volume of the disc being removed (8.7\% upon limited discectomy and $3.3 \%$ upon aggressive discectomy), but this is compensated for by a reduction in frequency of recurrent non-herniation back and leg pain (11 and 28\% upon limited and aggressive discectomy, respectively). ${ }^{21}$ Carragee et al. conducted a prospective study (I-1 level of evidence) in 180 patients with the median follow-up period of 6 years and revealed that the degree of annular defect after discectomy and herniation type is correlated with the reherniation rate. ${ }^{15}$ McGirt et al. found that the risk of disc reherniation increases in patients with annular defects wider than $6 \mathrm{~mm}$ and a smaller volume of disc removed. ${ }^{2,2} 2$

As we have mentioned earlier, there are few publications reporting the outcomes of using the Barricaid annular closure device; the results of randomized trials are not available. The existing studies were performed in small patient samples with the maximum follow-up period of 24 months.

We performed searches in the Scopus, Pubmed, and Google Scholar search engines using the keywords "Barricaid", "ACD", and "annular closure device". Table 5 lists the publications on the outcomes of using this device.

Lequin et al. performed a prospective study of 45 patients (follow-up period, 12 months) who had undergone limited discectomy and annular closure with the Barricaid device at the L4-L5 and L5-S1 levels. They reported a statistically significant decrease in pain intensity and improvement in quality of life. Revision surgery was needed in three cases: to manage ipsilateral disc reherniation in one patient; to the contralateral disc reherniation in another

Table 4. Reoperation rate, reason and treatment tactics.

\begin{tabular}{c|c|c|c|c|c}
\hline no. & Reason for reoperation & $\begin{array}{c}\text { Number of } \\
\text { patients }\end{array}$ & $\%$ & $\begin{array}{c}\text { Period of reoperation } \\
\text { (months) }\end{array}$ & Treatment tactics \\
\hline 1 & $\begin{array}{c}\text { Disc herniation at the operated } \\
\text { level on contralateral side }\end{array}$ & 1 & 0.8 & 6 & $2,6,18$ \\
\hline 2 & $\begin{array}{c}\text { Segmental instability of the } \\
\text { operated disc }\end{array}$ & 3 & 2.5 & 30 & $\begin{array}{c}\text { Reoperation, removal of the Barricaid annular closure } \\
\text { device, and rigid fixation of the segment }\end{array}$ \\
\hline 3 & $\begin{array}{c}\text { Ipsilateral disc reherniation at the } \\
\text { operated level }\end{array}$ & 1 & 0.8 & $\begin{array}{c}\text { Barricaid annular closure device, and rigid fixation } \\
\text { of the segment }\end{array}$ \\
\hline 4 & Epidural hematoma & 1 & 0.8 & $\begin{array}{c}\text { Early postoperative } \\
\text { period }\end{array}$ & Reoperation, removal of hematoma, and decompression \\
\hline & Total & 6 & 5 & & \\
\hline
\end{tabular}


Table 5. Review of the literature devoted to the Barricaid annular closure device.

\begin{tabular}{|c|c|c|c|c|c|c|c|c|c|}
\hline & Authors & Year & Journal & Design & $\begin{array}{c}\text { Number of } \\
\text { patients }\end{array}$ & $\begin{array}{l}\text { Follow-up } \\
\text { (months) }\end{array}$ & \begin{tabular}{|c|} 
Reherniation, \\
symp $(\%)$
\end{tabular} & \begin{tabular}{|c|} 
Reherniation, \\
asymp (\%) \\
\end{tabular} & $\begin{array}{c}\text { Reoperation } \\
(\%)\end{array}$ \\
\hline 1 & Lequin et al. & 2012 & Korean J spine & $\begin{array}{c}\text { Prospective, multi-center } \\
\text { study }\end{array}$ & 45 & 24 & 2.4 & 2.8 & 2.4 \\
\hline 2 & Trummer et al. & 2013 & $\begin{array}{c}\text { Clinical Neurology and } \\
\text { Neurosurgery }\end{array}$ & $\begin{array}{c}\text { Prospective, multi-center } \\
\text { study }\end{array}$ & 63 & 12 & NA & NA & NA \\
\hline 3 & Parker et al. & 2013 & $\begin{array}{c}\text { Journal of Neurological } \\
\text { Surgery }\end{array}$ & $\begin{array}{c}\text { A Multicenter } \\
\text { Prospective Cohort Study }\end{array}$ & 30 & 24 & 0 & 0 & 0 \\
\hline 4 & Bouma et al. & 2013 & Eur Spine J & Prospective & 75 & 24 & 1.4 & 5.1 & 1.3 \\
\hline 5 & Hahn et al. & 2014 & Korean J Neurotrauma & Case report & 3 & 12 & 0 & 0 & 0 \\
\hline 6 & Ledic et al. & 2015 & \begin{tabular}{|c|}
$\begin{array}{c}\text { Journal of Neurological } \\
\text { Surgery }\end{array}$ \\
\end{tabular} & Prospective & 75 & 24 & 1.5 & NA & 4.2 \\
\hline 7 & Barth et al. & 2016 & $\begin{array}{l}\text { Journal of Clinical } \\
\text { Neuroscience }\end{array}$ & Retrospective & 45 & 18 & 2.2 & NA & 8.9 \\
\hline 8 & Parker et al. & 2016 & \begin{tabular}{|c|} 
Journal of Spinal \\
Disorders \& Techniques \\
\end{tabular} & $\begin{array}{c}\text { A multi-center prospective } \\
\text { cohort study }\end{array}$ & 30 & 24 & 0 & NA & 0 \\
\hline 9 & Krutko et al. & 2016 & \begin{tabular}{|l|} 
International Journal of \\
Surgery Case Reports
\end{tabular} & Case report & - & - & - & - & - \\
\hline 10 & Lange et al. & 2017 & Acta Neurochir & Case report & - & - & - & - & - \\
\hline 11 & Klassen et al. & 2017 & Journal of Pain Research & $\begin{array}{c}\text { Post hoc analysis of a } \\
\text { randomized controlled trial }\end{array}$ & 272 & 3 & NA & NA & 1.9 \\
\hline 12 & \begin{tabular}{|c|} 
Adisa \\
Kuesumovich \\
et al.
\end{tabular} & 2017 & Cureus & Retrospective & 171 & 15 & 4.1 & 2.9 & 9.4 \\
\hline
\end{tabular}

patient; and to treat coarse cicatricial epidural lesions in the third patient. ${ }^{23}$ We observed no cicatricial changes requiring reoperation in our series. In their study with 2-year follow-up period, Parker et al. compared the outcomes of the conventional microdiscectomy and microdiscectomy using the Barricaid annular closure device. No disc reherniation was revealed in the group of patients who had undergone annular closure, while $6.5 \%$ of patients in the discectomy group had disc reherniation requiring revision surgery. ${ }^{24}$ Different authors reported that the short-term outcomes of limited discectomy followed by annular closure using the Barricaid device were comparable to those of the conventional discectomy. ${ }^{7,25}$ As reported by Lequin et al., the rate of symptomatic and asymptomatic reherniation following the use of the Barricaid annular closure device was 1.4 and $1.5 \%$, respectively. ${ }^{23}$ Bouma et al. conducted a prospective study of the effectiveness of the Barricaid annular closure device following limited microdiscectomy in 75 patients. After 12 months, 1.4\% of patients developed disc reherniation requiring reoperation and $1.5 \%$ of patients had asymptomatic reherniation. After 24 months, asymptomatic reherniation was present in $5.1 \%$ of patients. ${ }^{26}$ In our study, asymptomatic reherniation was found in two cases (1.7\%). Recurrent disc prolapses without clinical symptoms may be present in as many as $13 \%$ of discectomy patients two years after surgery. ${ }^{27}$

Trummer et al. demonstrated that annular closure slows down facet joint degeneration. ${ }^{28}$ We assessed the changes in degeneration of facet joints and the intervertebral disc and revealed no statistically significant worsening of degeneration during the follow-up period. Hence, the use of annular closure following discectomy allows the shape and function of facet joints and the intervertebral disc to be maintained.

Application of the annular closure device has a positive effect on the spinal motion segment by maintaining the intervertebral disc height. According to the published data, the height of the intervertebral disc may decrease as much as by $25 \%$ compared to the preoperative height, 2,6,8,9 which can be observed in clinical manifestations. Lequin et al. reported that intervertebral disc height after surgical removal of disc herniation followed by annular closure decreased by only $7 \%$ from the baseline level. ${ }^{23}$ We also revealed no statistically significant disc height loss, indicating that the Barricaid annular closure device can reliably protect the intervertebral disc injured during limited discectomy.

The emergence of resorption foci of bone tissue around the implant is one of the negative radiographic outcomes after implanting the Barricaid device. We revealed that these foci mainly occur at the sites where the end of the implant mesh or anchor contacts the endplate of an adjacent vertebra. In their retrospective study, Barth et al. ${ }^{29}$ assessed the discal and non-discal changes after closure of annular defect in 45 patients. The control group consisted of 40 patients who had undergone sequestrectomy alone (group S). The inclusion criteria were identical; the follow-up period ranged between 18 and 27 months. Those authors revealed that disc reherniation in the sequestrectomy group was reliably higher (12.5 and 2.2\%); patients in the S group more often had an annular defect confirmed by MRI. Postoperative Modic changes were observed in one patient in each group. The rate of vertebral endplate changes presenting as small cysts, erosion, and bone tissue resorption was reliably higher in patients with implanted annular closure devices (52.4 and 10.3\%). These changes were mostly detected around the polyethylene terephthalate Mesh. No correlation between the clinical treatment outcomes and the MRI data were revealed in this study.

Lange et al. reported a case of low-grade infectious process around the Barricaid annular closure device five years following the surgery. Lumbar spine MSCT revealed bone tissue resorption around the implant. Bacteriological examination showed propionibacterium acnes colonization. ${ }^{30}$

The study by Kursumovich et al. ${ }^{31}$ is one of the most recent publications devoted to the Barricaid device. Those authors performed a retrospective analysis of the outcomes of microdiscectomy and annular closure in 171 patients. The mean follow-up period was 15 months. Disc reherniation was revealed in $4.1 \%$ of cases; asymptomatic disc reherniation was observed in $2.9 \%$ of patients. Fifteen (8.8\%) patients had either partial or complete detachment of the polymer mesh from the titanium anchor. Only two of these patients were reoperated. We observed no mesh detachment in our cases. The mesh was turned towards the spinal canal in two patients $(1.7 \%)$, but it still was attached to the titanium anchor. These changes were detected three and 18 months postoperatively, respectively. The patients presented with no recurrent disc herniation and/or pain syndrome. Penetration of the implant mesh into the adjacent vertebral endplate was observed in nine cases (7.4\%).

Our study has a number of limitations: its design involved neither randomization nor a control group; the follow-up periods ranged from two to 60 months; the interventions were performed by different surgeons; and no independent evaluation of the radiographic and MRI data was carried out. These facts may have potentially biased the study results. 


\section{CONCLUSIONS}

The use of Barricaid annular closure device in 120 patients with lumbar disc herniation and high risk of recurrent herniation showed good clinical and radiographic outcomes. The disc height was maintained; no reliable decrease in this parameter was observed at follow-up points. The reoperation rate in our study was $2.5 \%$; disc reherniation at the operated level was observed in $1.7 \%$ of patients. This is a good outcome compared to data reported for patients with a high risk of disc reherniation. Disc reherniation or bone tissue resorption around the implant requiring revision surgery is possible. Large randomized trials are needed to evaluate whether wide the application of this annular closure device is feasible.

All authors declare no potential conflict of interest related to this article.

CONTRIBUTION OF THE AUTHORS: Each author made significant individual contributions to this manuscript. SAJ (0000-0002-4744-4077)* and KAV (0000-0002-2570-3066)* were the main contributors in the drafting of the manuscript. BES (0000-0002-4430-700X)*, SAJ and KAV performed the surgery, followed up patients, and gathered clinical data. SAJ and LAA (0000-0003-0620-3119)* evaluated the data from the statistical analysis. SAJ, KAV and LAA performed the literature search and review of the manuscript, and contributed to the intellectual concept of the study. ${ }^{*}$ ORCID (Open Researcher and Contributor ID).

\section{REFERENCES:}

1. Peul WC, van den Hout WB, Brand R, Thomeer RT, Koes BW. Prolonged conservative care versus early surgery in patients with sciatica caused by lumbar disc herniation: two year results of a randomised controlled trial. BMJ. 2008;336(7657):1355-8.

2. McGirt MJ, Eustacchio S, Varga P, Vilendecic M, Trummer M, Gorensek $M$ et al. A prospective cohort study of close interval computed tomography and magnetic resonance imaging after primary lumbar discectomy: factors associated with recurrent disc herniation and disc height loss. Spine (Phila Pa 1976). 2009;34(19):2044-51.

3. Strumqvist B, Fritzell P, Hagg O, Jonsson B. One - year report from the Swedish National Spine Register. Acta Orthop Suppl. 2005;76(319):1-24.

4. Camino Willhuber G, Kido G, Mereles M, Bassani J, Petracchi M, Elizondo C et al. Factors associated with lumbar disc hernia recurrence after microdiscectomy. Rev Esp Cir Ortop Traumatol. 2017;61(6):397-403.

5. Byvaltsev VA, Kalinin AA, Belykh EG, Sorokovikov VA, Shepelev VV. [Optimization of segmental lumbar spine instability treatment using minimally invasive spinal fusion technique]. Zh Vopr Neirokhir Im N N Burdenko. 2015;79(3):45-54.

6. Barth M, Diepers M, Weiss $C$, Thomé C. Two-year outcome after lumbar microdiscectomy versus microscopic sequestrectomy: part 2: radiographic evaluation and correlation with clinical outcome. Spine (Phila Pa 1976). 2008;33(3):273-9.

7. Carragee EJ, Spinnickie AO, Alamin TF, Paragioudakis S. A prospective controlled study of limited versus subtotal posterior discectomy: short-term outcomes in patients with herniated lumbar intervertebral discs and large posterior annulus defect. Spine (Phila Pa 1976). 2006;31(6):653-7.

8. Loupasis GA, Stamos K, Katonis PG, Sapkas G, Korres DS, Hartofilakidis G. Seven- to 20-year outcome of lumbar discectomy. Spine (Phila Pa 1976). 1999:24(22):2313-7.

9. Yorimitsu E, Chiba K, Toyama Y, Hirabayashi K. Long-term outcomes of standard discectomy for lumbar disc herniation: a follow-up study of more than 10 years. Spine (Phila Pa 1976). 2001:26(6):652-7.

10. Ambrossi GL, McGirt MJ, Sciubba DM, Witham TF, Wolinsky JP, Gokaslan ZL, et al. Recurrent lumbar disc herniation after single-level lumbar discectomy: incidence and health care cost analysis. Neurosurgery.2009:65(3):574-8.

11. Atlas SJ, Keller RB, WuYA, Deyo RA, Singer DE. Long-term outcomes of surgical and nonsurgical management of sciatica secondary to a lumbar disc herniation: 10 year results from the maine lumbar spine study. Spine (Phila Pa 1976). 2005;30(8):927-35

12. Belykh E, Krutko AV, Baykov ES, Giers MB, Preul MC, Byvaltsev VA. Preoperative estimation of disc herniation recurrence after microdiscectomy: predictive value of a multivariate model based on radiographic parameters. Spine J. 2017;17(3):390-400.

13. Malter AD, McNeney B, Loeser JD, Deyo RA. 5-year reoperation rates after different types of lumbar spine surgery. Spine (Phila Pa 1976). 1998;23(7):814-20.

14. Belykh E, Giers MB, Preul MC, Theodore N, Byvaltsev V. Prospective Comparison of Microsurgical, Tubular-Based Endoscopic, and Endoscopically Assisted Diskectomies: Clinical Effectiveness and Complications in Railway Workers. World Neurosurg. 2016;90;273-80.

15. Carragee, E, Han MY, Suen PW, Kim D. Clinical outcomes after lumbar discectomy for sciatica: the effects of fragment type and annular competence. J Bone Joint Surg Am. 2003;85-A(1):102-8.
16. Weinstein JN, Lurie JD, Tosteson TD, Tosteson AN, Blood EA, Abdu WA et al. Surgical versus nonoperative treatment for lumbar disc herniation: four-year results for the Spine Patient Outcomes Research Trial (SPORT). Spine (Phila Pa 1976). 2008; 33(25):2789-800.

17. Kim KT, Park SW, Kim YB. Disc height and segmental motion as risk factors for recurrent lumbar disc herniation. Spine (Phila Pa 1976). 2009;34(24):2674-8.

18. Pfirrmann CW, Metzdorf A, Zanetti M, Hodler J, Boos N. Magnetic resonance classification of lumbar intervertebral disc degeneration. Spine (Phila Pa 1976). $2001 ; 26(17): 1873-8$.

19. Grogan J, Nowicki BH, Schmidt TA, Haughton VM. Lumbar facet joint tropism does not accelerate degeneration of the facet joints. AJNR Am J Neuroradiol. 1997:18(7):1325-9.

20. Fardon DF, Milette PC. Nomenclature and classification of lumbar disc pathology. Recommendations of the Combined task Forces of the North American Spine Society, American Society of Spine Radiology, and American Society of Neuroradiology. Spine (Phila Pa 1976). 2001;26(5):E93-113.

21. Watters WC 3ed, McGirt MJ. An evidence-based review of the literature on the consequences of conservative versus aggressive discectomy for the treatment of primary disc herniation with radiculopathy. Spine J. 2009;9(3):240-57.

22. McGirt MJ, Ambrossi GL, Datoo G, Sciubba DM, Witham TF, Wolinsky JP et al. Recurrent disc herniation and long-term back pain after primary lumbar discectomy: review of outcomes reported for limited versus aggressive disc removal. Neurosurgery. 2009;64(2):338-44.

23. Lequin MB, Barth $M$, Thome $C$, Bouma G. Primary Limited Lumbar Discectomy with an Annulus Closure Device: One-Year Clinical and Radiographic Results from a Prospective, Multi-Center Study. Korean J Spine. 2012;9(4):340-7.

24. Parker SL, Grahovac G, Vukas D, Vilendecic M, Ledic D, McGirt MJ, Carragee EJ. Effect of an Annular Closure Device (Barricaid) on Same Level Recurrent Disc Herniation and Disc Height Loss after Primary Lumbar Discectomy:Two-Year Results of a Multi-Center Prospective Cohort Study. Clin Spine Surg. 2016;29(10):454-60.

25. Arts MP Brand $\mathrm{R}$, van den Akker ME, Koes BW Bartels $\mathrm{RH}$, Peul WC et al. Tubular diskectomy vs conventional microdiskectomy for sciatica: a randomized controlled trial. JAMA. 2009;302(2):149-58.

26. Bouma GJ, Barth $M$, Ledic D, Vilendecic $M$ et al. The high-risk discectomy patient: prevention of reherniation in patients with large anular defects using an anular closure device. Eur Spine J. 2013;22(5):1030-6.

27. Lebow RL, Adogwa O, Parker SL, Sharma A, Cheng J, McGirt MJ. Asymptomatic same-site recurrent disc herniation after lumbar discectomy: results of a prospective longitudinal study with 2-year serial imaging. Spine (Phila Pa 1976). 2011;36(25):2147-51.

28. Trummer M, Eustacchio S, Barth M, Klassen PD, Stein S. Protecting facet joints post-lumbar discectomy: Barricaid annular closure device reduces risk of facet degeneration. Clin Neurol Neurosurg. 2013;115(8):1440-5.

29. Barth M., Fontana J, Thomé C, Bouma GJ, Schmieder K. Occurrence of discal and non-discal changes after sequestrectomy alone versus sequestrectomy and implantation of an anulus closure device. J Clin Neurosci. 2016;34:288-93.

30. Lange N, Meyer B, Shiban E. Symptomatic annulus-repair-device loosening due to a low-grade infection. Acta Neurochir (Wien). 2017;160(1):199-203.

31. Kuršumović A, Rath S. Performance of an Annular Closure Device in a 'Real-World', Heterogeneous, At-Risk, Lumbar Discectomy Population. Cureus. 2017;9(11):e1824. 